DOI: $10.5277 /$ epe 160414

\title{
SPATIAL DISTRIBUTION OF MANGANESE AND IRON IN SEDIMENTS OF THE CZORSZTYN RESERVOIR
}

\begin{abstract}
Concentrations of iron and manganese were investigated in 26 sediment samples from the Czorsztyn Reservoir (South Poland). Spatial distribution of these metals in the reservoir is generally linked to the grain size distribution of sediments. The presence of manganese and iron in sediments is mainly related to the rock weathering and soil erosion processes. Furthermore, enrichment of waters in manganese and iron follows as a result of the Dunajec River flowing through the Orawsko-Nowotarska Valley, where peat bogs are present. However, anthropogenic influence on manganese and iron concentration levels in sediments cannot be excluded in this area.
\end{abstract}

\section{INTRODUCTION}

Trace metals constitute an integral element of aquatic ecosystems, and consequently of bottom sediments. They get into waters both as a result of natural processes, as well as anthropogenic activities. Geochemical formation of catchment, weather conditions and human activities have an essential influence on the sediment composition [1-5]. This paper focuses on the presence of manganese and iron in bottom sediments of the Czorsztyn Reservoir. Previous studies investigated only the range of manganese concentrations in water, bottom sediments and suspension of the Dunajec River upstream and downstream from the reservoir [6]. The distribution of both metals in the reservoir sediments has not been discussed yet.

The Czorsztyn Reservoir was created by damming of the Vistula River tributary, the Dunajec River, at the $173.3 \mathrm{~km}$. The Czorsztyn Reservoir serves several functions,

${ }^{1}$ Institute of Water Supply and Environmental Protection, Cracow University of Technology, ul. Warszawska 24, 31-155 Kraków, Poland, corresponding author A. Czaplicka, e-mail: anna.czaplicka@pk.edu.pl

${ }^{2}$ Institute of Nature Conservation, Polish Academy of Sciences, al. Mickiewicza 33, 31-120 Kraków, Poland. 
mainly flood protection, energy production, and recreation. The catchment of the Czorsztyn Reservoir is extensive $\left(1147 \mathrm{~km}^{2}\right)$, geologically diverse, and differentially developed. Waters from the Tatra Mountains, Rów Podhalański, Pogórze Spisko-Gubałowskie, Orawsko-Nowotarska Valley, and the Pieniny and Gorce Mountains discharge into the reservoir via the Dunajec and Biakka Rivers, and also numerous streams, which are direct tributaries of the Czorsztyn Reservoir.

The present study examines concentrations of manganese and iron in bottom sediments of the Czorsztyn Reservoir and their spatial distribution, and attempts to explain their origin. Correlations of metal concentrations with grain size, organic matter and carbonates have also been discussed.

\section{MATERIALS AND METHODS}

Surface sediment samples were collected with a standard Ekman Grab from 26 sites situated along the lengthwise transects (Fig. 1). Then the collection samples were mixed and stored in plastic bags. In the laboratory, sediments were dried at $105^{\circ} \mathrm{C}$ and homogenized prior $\mathrm{Mn}$ and $\mathrm{Fe}$, grain size, organic matter, carbonate analyses.

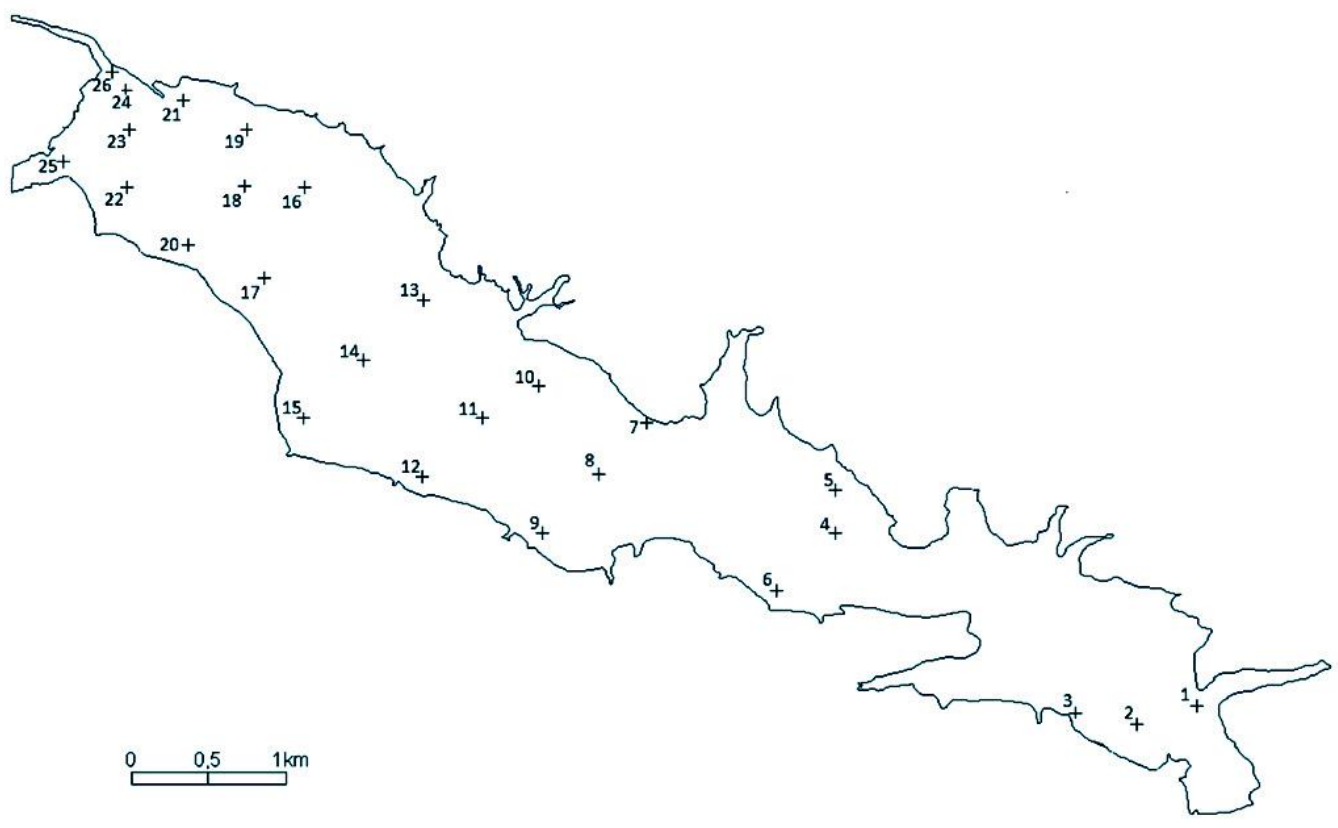

Fig. 1. Distribution of sampling sites in the Czorsztyn Reservoir 
Laser diffraction technique employed to analyze the grain size distribution (Coulter 100Q laser diffraction particle size analyzer) enabled determination of three fractions: sandy $(1-0.063 \mathrm{~mm})$, silty clay $(0.063-0.002 \mathrm{~mm})$ and clay $(<0.002 \mathrm{~mm})$ [7]. The fraction with a diameter greater than $1 \mathrm{~mm}$ was discarded. Organic matter content was determined using loss on ignition technique, involving combustion of samples at $550{ }^{\circ} \mathrm{C}$ to reach a constant weight. Carbonates were determined using the Scheibler's volumetric method.

Manganese and iron concentrations were determined by the atomic absorption spectroscopy (AAS) using a Varian Spectra AA-20 atomic absorption spectophotometer with atomization in air-acetylene flame. The detection limits were $2 \mu \mathrm{g} \cdot \mathrm{dm}^{-3}$ for $\mathrm{Mn}$, and $6 \mu \mathrm{g} \cdot \mathrm{dm}^{-3}$ for Fe. Measurements were preceded by mineralization of samples (with replicates) with $10 \mathrm{~cm}^{3}$ of $65 \% \mathrm{HNO}_{3}$ in a microwave digestion system Speedwave (Berghof). Sediment reference material (NCS DC 73308, river sediment) was used to check accuracy of the analytical methods. Measured concentrations of $\mathrm{Mn}$ in the sample was $1001 \pm 7 \mathrm{mg} \cdot \mathrm{kg}^{-1}$, while the certified Mn content was $1010 \pm 29 \mathrm{mg} \cdot \mathrm{kg}^{-1}$.

Statistical analysis of the obtained results was performed using their rang distributions. Mann-Whitney $\mathrm{U}$ test was used to examine the differences between average iron or manganese concentrations in groups formed by assigning to the each measurement one of the two values of the considered attribute (belonging of the measuring points to a given transect or to the remaining area of the reservoir). Spearman's rank correlation coefficient was used to analyze correlations between concentrations of metals, grain size distribution, organic matter, carbonates, and depth of the reservoir. Similarities of samples in respect of $\mathrm{Mn}$ and $\mathrm{Fe}$ concentrations are presented in the form of a dendrogram (hierarchical cluster analysis). In order to the estimate contamination level, the geoaccumulation index was calculated. Threshold values LEL and SEL [8] were used to define potential negative influence of sediments on benthic organisms. Fe and Mn concentrations were also compared with the results of similar surveys for the other dam reservoirs in Poland.

\section{RESULTS}

Grain-size distribution revealed that sediments sampled from the Czorsztyn Reservoir are dominated by silty clay fraction $(0.063-0.002 \mathrm{~mm})$, with the average amount of $59.2 \%$. Sandy fraction $(1-0.063 \mathrm{~mm})$ predominated only in samples collected near the estuaries of the Dunajec and Białka Rivers, and also in sediments from site 13, which is situated close to the outlet of the local tributary. The highest content (40.6\%) of clay fraction $(<0.002 \mathrm{~mm})$ was observed in the vicinity of the dam (site 2$)$. In the middle part of the reservoir, where the depth reaches $30 \mathrm{~m}$, distinct increase of silty clay fraction was observed, while close to the dam, where the depth exceeds $30 \mathrm{~m}$, the clay fraction content was elevated. 
Organic matter content ranged from $4.7 \%$ at site 19 to $11.2 \%$ at site 2 with the average amount equal to $6.2 \%$. Values exceeding the average amount were observed in the middle and lower parts of the reservoir, particularly along the main axis and the right shore. Carbonate content was in the range of 4.7-8.6\%. Higher values were observed in samples collected from sites situated also along the right shore.

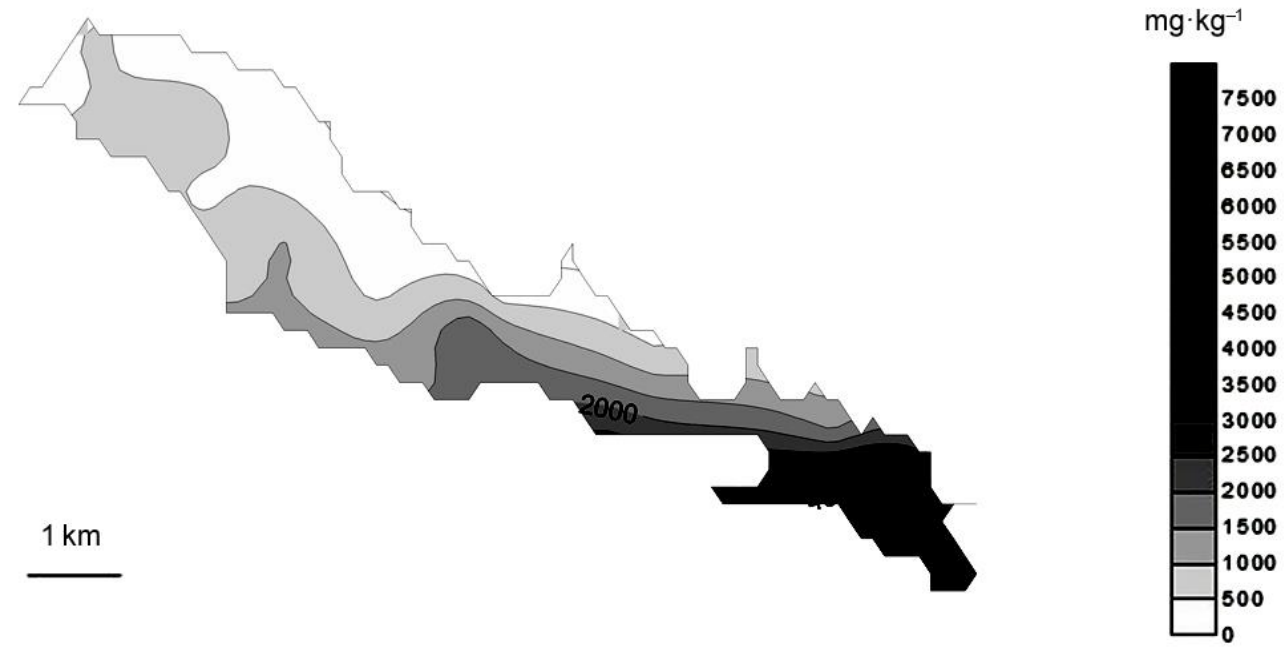

$\mathrm{mg} \cdot \mathrm{kg}^{-1}$

Fig. 2. Spatial distribution of Mn concentrations in sediments of the Czorsztyn Reservoir

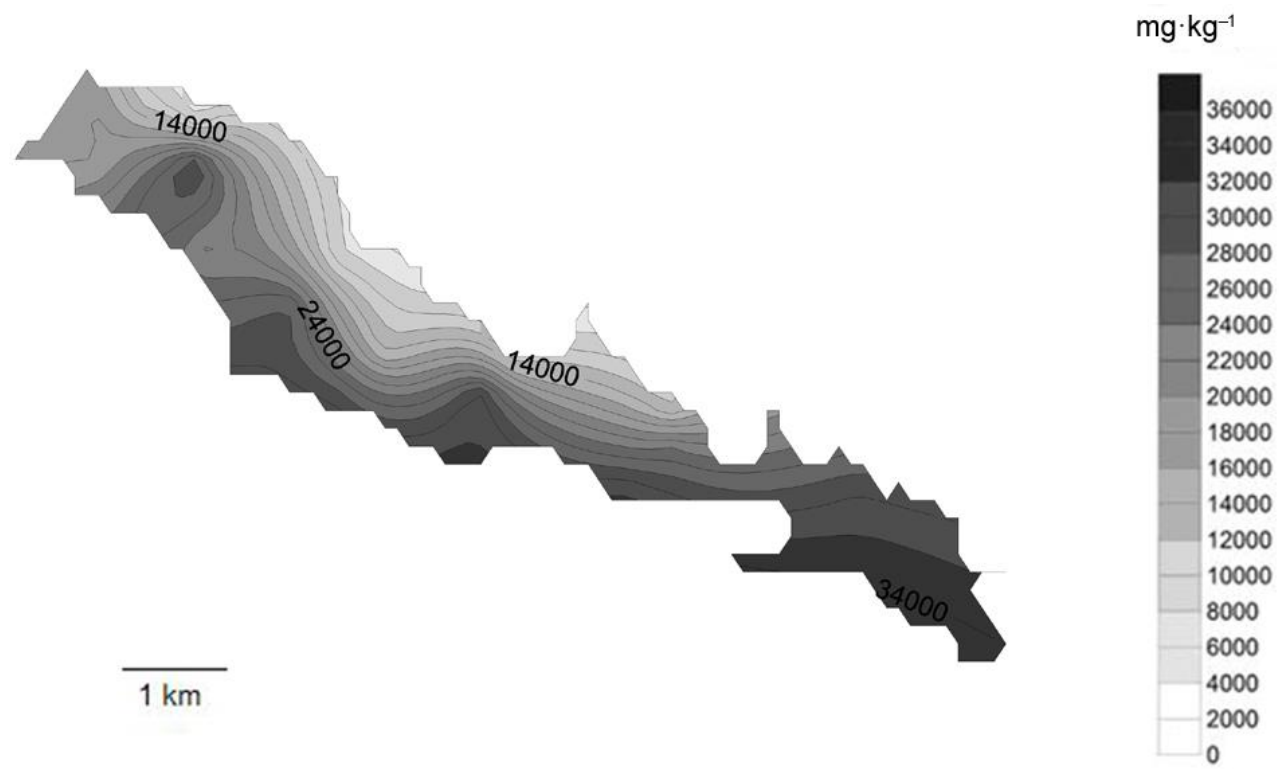

Fig. 3. Spatial distribution of Fe concentrations in sediments of the Czorsztyn Reservoir 
Mn concentrations ranged from 237 to $7372 \mathrm{mg} \cdot \mathrm{kg}^{-1} \mathrm{DW}$ and the increasing trend towards the dam was observed (Fig. 2). Also, a distinct difference between left and right bank of the reservoir has been observed. Mn concentrations were significantly higher $(p<0.05)$ at the sites located at the right side of the reservoir than in the left one, and also in the central part.

The spatial distribution pattern of Fe was similar to the Mn one. Fe concentrations ranged from 8120 to $34060 \mathrm{mg} \cdot \mathrm{kg}^{-1} \mathrm{DW}$ and low concentrations were observed in the middle part, and in the left bank of the reservoir (Fig. 3). High Fe concentrations were noted in sites located close to the dam and also in the upper part of the reservoir, close to the main axis.

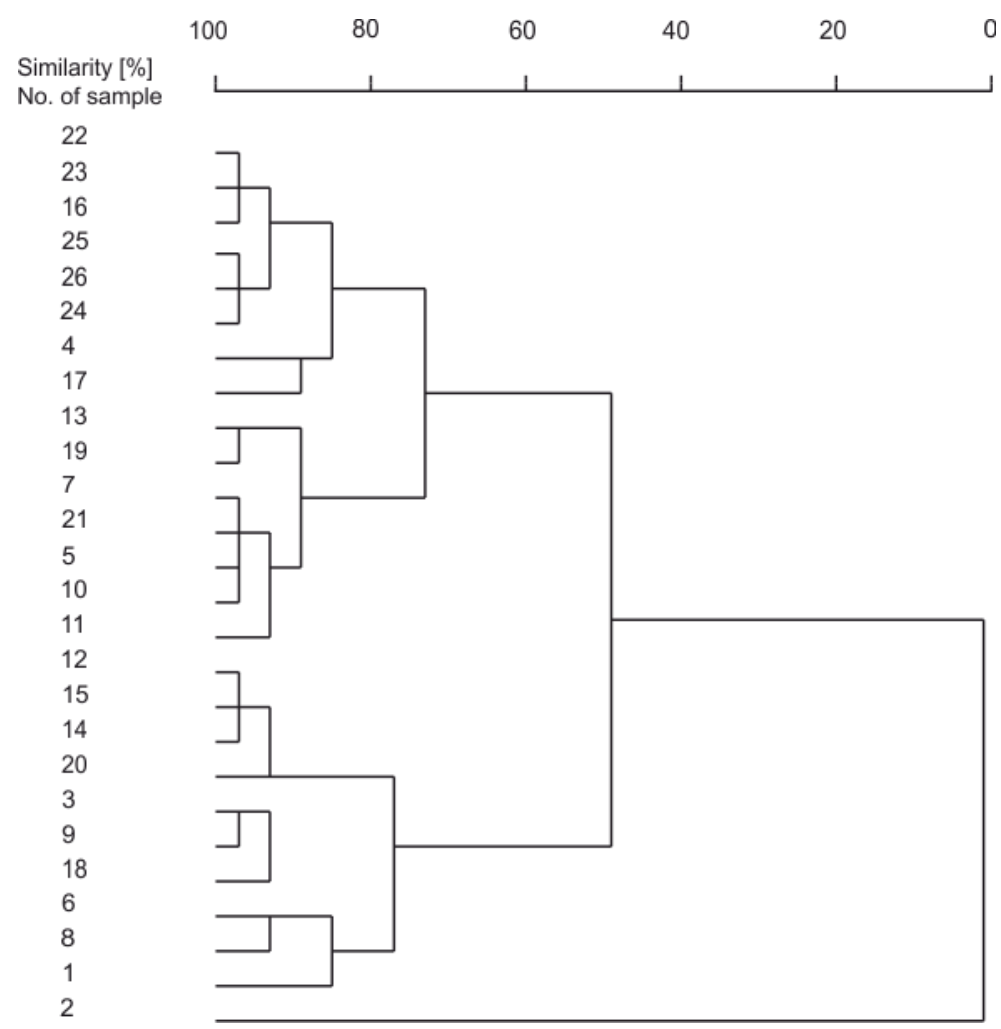

Fig. 4. Dendrogram of similarities among the sediment samples from the Czorsztyn Reservoir

Similarities among the samples regarding $\mathrm{Mn}$ and Fe concentrations were assessed by the hierarchical cluster analysis. In the output dendrogram, two groups of sites can be distinguished (Fig. 4). To the first group belonged sites situated along the left bank of the reservoir (where local streams discharge their waters) and stations near to the outlets of the Dunajec and Białka Rivers. The second group was created by sites located along the right bank of the reservoir (except for the sites in the outlet of the Białka River 
area), and near to the dam. In site 2, which does not fit to the any of the groups and is situated next to the dam, the highest concentrations of $\mathrm{Mn}$ and Fe were observed.

Table 1

Spearman's rank correlation coefficients of $\mathrm{Mn}$ and Fe with the grain size fractions, reservoir depth, organic matter and carbonates in the Czorsztyn Reservoir

\begin{tabular}{|c|c|c|c|c|c|c|}
\hline \multirow{2}{*}{ Metal } & \multicolumn{3}{|c|}{ Fraction } & \multirow{2}{*}{ Depth } & \multirow{2}{*}{ Organic matter } & \multirow{2}{*}{ Carbonates } \\
\cline { 2 - 4 } & Clay & Silty clay & Sand & & & \\
\hline $\mathrm{Mn}$ & 0.73 & 0.65 & -0.79 & 0.66 & 0.82 & 0.78 \\
\hline $\mathrm{Fe}$ & 0.72 & 0.71 & -0.81 & 0.64 & 0.90 & 0.86 \\
\hline
\end{tabular}

Correlations of $\mathrm{Fe}$ and $\mathrm{Mn}$ concentrations with the grain size fractions, depth of the reservoir, organic matter, and carbonates are presented in Table 1. The highest coefficient values were observed for organic matter. Positive values were obtained also for carbonates, clay and silty clay fractions and the reservoir depth (high and very high correlations). All coefficients were statistically significant at $p<0.05$ level.

\section{DISCUSSION}

Fe concentrations in the area of the Czorsztyn Reservoir balanced on the level of the value usually assumed as the geochemical background, which is $47220 \mathrm{mg} \cdot \mathrm{kg}^{-1} \mathrm{DW}$ [9]. Manganese concentration in bottom sediments exceeded the value established as the natural background at $42 \%$ of the stations. The value of $850 \mathrm{mg} \cdot \mathrm{kg}^{-1} \mathrm{DW}$ was adopted as the geochemical background of manganese [9]. A direct determination of the geochemical background is difficult, particularly for such specific ecosystems as dam reservoirs.

Pasieczna and Lis [11] informed that before the reservoir was built, manganese concentration in the bottom sediments of the Dunajec River and its local tributaries had been at the level of $500 \mathrm{mg} \cdot \mathrm{kg}^{-1} \mathrm{DW}$, whereas the results of surveys from years 2000-2001 showed that manganese concentrations oscillated between 300 and $1900 \mathrm{mg} \cdot \mathrm{kg}^{-1} \mathrm{DW}[6,10]$. The amount of iron was lower than $10000 \mathrm{mg} \cdot \mathrm{kg}^{-1} \mathrm{DW}$ [11].

In order to estimate the contamination of sediments by trace metals, the geoaccumulation index Igeo was calculated [12]. According to Müller's classification scheme based on Igeo values, sediments were classified in the range of uncontaminated-moderately contaminated in respect to manganese content, and uncontaminated in respect to iron content. Elevated metal content in water ecosystems very often results from the natural fluctuation of metal concentrations in various geological structures [13]. The drainage area is very diversified geologically. The reservoir is located directly in the Pieniny Klippen Belt constituted mainly of carbonate rocks which favours the formation 
of manganese and iron concentrations thanks to the amalgamation of the cations of these metals with $\mathrm{CO}_{3}^{2-}$ anions present in carbonates [14]. Waters of the Dunajec River are enriched with discussed metals also in Western Tatras, where small manganese and iron ores are present, as well as in the Orawsko-Nowotarska Basin, where numerous peat bogs can be found. In this area, local concentrations of manganese in bottom sediments of the Dunajec River exceeded $4000 \mathrm{mg} \cdot \mathrm{kg}^{-1}$ [11]. In the Carpathians, increased concentrations of manganese and iron in soils are observed which is connected with the chemical composition of bedrocks. Silty soils made of flysch are especially rich in manganese. In the shales of the Carpathian flysch, manganese occurs to the amount of 2360 $\mathrm{mg} \cdot \mathrm{kg}^{-1}$ [11]. The attempt of determination whether manganese is an anthropogenic contaminant or comes from natural sources is based on the drainage area analysis. This area is slightly industrialized and is characterized by the high environmental value and the presence of extensive legally protected terrains (the Tatra National Park, the Pieniny National Park). The main source of water contamination with manganese and iron may be municipal waste water and dust precipitation coming from burning fossil fuels in local boiler houses and domestic furnaces. Moreover, as far as manganese is concerned, the potential source of pollution can be artificial phosphate fertilizers getting into waters as a result of surface run-offs. The studies showed, however, that point sources have greater influence on manganese concentration than surface run-offs [1].

$\mathrm{Mn}$ and $\mathrm{Fe}$ concentrations were also compared with the results of the surveys in other dam reservoirs in Southern Poland. The Goczałkowice Reservoir, the Rybnik Reservoir situated in Silesia region and the Dobczyce Reservoir located in Małopolska Province were considered. The results of the comparison are shown in the Table 2.

Table 2

The juxtaposition of managnese and iron concentrations $\left[\mathrm{mg} \cdot \mathrm{kg}^{-1} \mathrm{DW}\right]$ in bottom sediments of the chosen dam reservoirs

\begin{tabular}{|l|l|c|c|c|c|}
\hline \multirow{2}{*}{\multicolumn{1}{c|}{ Reservoir }} & \multirow{2}{*}{ River } & \multicolumn{2}{c|}{ Fe } & \multicolumn{2}{c|}{ Mn } \\
\cline { 3 - 6 } & & Minimal & Maximal & Minimal & Maximal \\
\hline Czorsztyn & Dunajec & 8120 & 34060 & 240 & 7370 \\
\hline Goczałkowice [15] & Wisła & 130 & 39000 & 40 & 1180 \\
\hline Dobczyce [1] & Raba & 6700 & 33500 & 300 & 3300 \\
\hline Rybnik [16] & Ruda & 3300 & 48800 & 170 & 2800 \\
\hline
\end{tabular}

Manganese concentrations in the Czorsztyn Reservoir were higher than those in the reservoirs in Goczałkowice, Dobczyce and Rybnik. The drainage basin of the Czorsztyn Reservoir is industrialized to a lesser extent than the one of the Goczałkowice Reservoir what suggests geochemical origin of this trace metal in the sediments of the Czorsztyn Reservoir. The Rybnik Reservoir is located on the terrain of the Rybnik Coal Basin and 
is therefore highly exposed to anthropopressure but its manganese concentrations were lower than the concentrations in the Czorsztyn Reservoir.

The Czorsztyn Reservoir, apart from high concentrations of metals near the dam, is characterized by manganese and iron concentrations similar to maximal concentrations of these elements in the Dobczyce Reservoir. Szarek-Gwiazda [1] described the Dobczyce Reservoir as slightly contaminated and also informed that the main sources of manganese were municipal waste water and diffuse pollution and the main source of iron was diffuse pollution. It can be said that anthropogenic activity has little influence on the amount of manganese content in bottom sediments.

Grain size of the bottom sediments of the Czorsztyn Reservoir are characterized by the spatial variability due to reduction of flow velocity. The coarse material was deposited near the estuaries of the rivers and after that the deposition of the fine material follows. Occurrence of different type sediments areas might be linked to the presence of local sources of clastic material supply and to hydro-dynamical changes in the reservoir which may cause resuspention or movement of the accumulated material [17].

The grain size segregation visible in the Czorsztyn Reservoir, i.e. increase of silty clay content to the depth of $30 \mathrm{~m}$, and then increase of clay fraction content towards the dam resulted from the hydrodynamical processes run in the reservoir. Slower water movement in the deeper part of the reservoir favours sedimentation of the finest fractions. Therefore, in the sediments of the deepest zone of the reservoir, accumulation of clay fractions and organic matter was noticed [17]. Accumulation of carbonates, silty clay fraction and organic matter occurred also along the right bank. High content of carbonates was most likely connected to the presence of numerous limestone outcrops on the right side of the reservoir. Studied parameters, i.e. the depth of reservoir, contents of clay fraction, carbonates and organic matter favour accumulation of $\mathrm{Mn}$ and $\mathrm{Fe}$ in the sediments (positive correlation). It is known that clay minerals are characterized by negative charge and with the aid of $\mathrm{OH}$ groups take part in chemisorption [18]. Silty clay and clay fractions, due to their high content in sediments, play the dominant role in accumulation of trace metals in bottom sediments of the Carpathian dam reservoirs [1]. In the area of Czorsztyn Reservoir, the clay fraction seems to be of higher importance regarding to $\mathrm{Mn}$, while, as far as $\mathrm{Fe}$ is concerned, both clay and silty clay fractions are of equal relevance, what explains differences in spatial distribution of these elements. Similar conclusion was made by Szarek-Gwiazda [1]. Positive relationships between the contents of $\mathrm{Mn}$ and $\mathrm{Fe}$ and the clay fraction were also found in other reservoirs [19].

Organic matter appears in relatively small amounts (an average of 6\%) in the sediment of the Czorsztyn Reservoir which suggests that it has lesser impact on spatial distribution of discussed elements in the reservoir sediment than mineral fractions.

Positive correlation $\left(r_{s}=0.94\right)$ between $\mathrm{Mn}$ and $\mathrm{Fe}$ may indicate their similar sources or that they undergo similar physicochemical processes in the reservoir. They are components of aluminosilicates which are constituents of many rock type, mostly magmatic ones; are present in reduction ecosystems of peat bogs and appear in ground 
water. In the analyzed bottom sediments, the ratio of manganese to iron fluctuated between 1:5 and 1:58. Manganese in an aquatic environment is more mobile than iron, thereby is more susceptible to physical and chemical changes of water conditions. Local disproportion can be observed in the south-west part of the reservoir (Figs. 2, 3), which may also be connected to anthropogenic contaminates.

Manganese and iron present in sediments in the form of hydroxides have the ability to absorb other trace metals. The presence of $\mathrm{Mn}$ and $\mathrm{Fe}$ compounds furthers accumulation of other metals $[1,20]$ in the Czorsztyn Reservoir, e.g. $\mathrm{Cu}, \mathrm{Zn}, \mathrm{Cr}$. It has to be considered that a change in reduction-oxidation conditions or $\mathrm{pH}$ in the reservoir may cause the release of metals from bottom sediments into water $[10,21]$. The toxicity of manganese and iron in natural conditions occurs very rarely and the majority of organisms show tolerance to high concentrations of these elements. Nonetheless, the assessment of the quality of analyzed sediments in consideration of their toxicological influence on benthic organisms was done by using threshold values LEL (lowest effect level) and SEL (severe effect level), which are: for Mn LEL $-460 \mathrm{mg} \cdot \mathrm{kg}^{-1} \mathrm{DW}$, SEL - $1100 \mathrm{mg} \cdot \mathrm{kg}^{-1} \mathrm{DW}$; for Fe LEL - $20000 \mathrm{mg} \cdot \mathrm{kg}^{-1} \mathrm{DW}$, SEL - $40000 \mathrm{mg} \cdot \mathrm{kg}^{-1}$ DW [8]. Obtained results allow to state that regarding manganese the LEL value was exceeded in 15 stations and the SEL one in 7 stations. Iron content did not exceed the LEL value in 13 stations and in others oscillated between the LEL and SEL values. Therefore potential negative influence on benthic organisms can be expected.

\section{CONCLUSIONS}

Manganese and iron concentrations in bottom sediments of the Czorsztyn Reservoir were mainly influenced by geochemical processes in the drainage area, i.e. the weathering of rocks and erosion of soils. The enrichment of waters in $\mathrm{Mn}$ and $\mathrm{Fe}$ was also caused by the Dunajec River flowing through the Orawsko-Nowototarska Basin, where peat bogs were present. Partly anthropogenic influence (municipal waste water, diffuse pollution and dust precipitation coming from burning fossil fuels) on manganese and iron concentrations in bottom sediments cannot be precluded.

Spatial distribution of $\mathrm{Mn}$ and $\mathrm{Fe}$ concentrations in the sediments of the reservoir was connected with the sediments' composition: organic matter and carbonates content, grain sizes and reservoir depth. Due to small amounts of organic matter in sediments (up to a few percent), mineral fractions seem to be the most important factor differentiating manganese and iron concentrations in bottom sediments of the Czorsztyn Reservoir.

\section{ACKNOWLEDGEMENT}

The study was partially financed by the State Committee for Scientific Research KBN (grant No. 539/PO4/2005/28), the Swiss National Science Foundation (grant No. 200020-101844) and partly by the Institute of Nature Conservation of Polish Academy of Sciences, Kraków, Poland. 


\section{REFERENCES}

[1] SZAREK-GwIAZDA E., Factors influencing the concentrations of heavy metals in the Raba River and selected Carpathian dam reservoirs, Studia Naturae, 60, PAN, Cracow 2013 (in Polish).

[2] SZAREK-GwiAZDA E., SADOWSKa I., Distribution of grain size and organic matter content in sediments of submontane dam reservoir, Environ. Prot. Eng., 2010, 36 (1), 113.

[3] Kwapuliński J., WiechuŁa D., Migration of lead and cadmium in Goczalkowice dam reservoir (southern Poland), Acta Hydrobiol., 1992, 34, 1-2, 43.

[4] SKorbiŁowicz M., SkorbiŁowicz E., Assessment of heavy metal content in bottom sediments of river Supraśl and its tributaries, Environ. Prot. Eng., 2009, 35 (3), 3, 279.

[5] Zerbe J., SobczyŃSki T., Elbanowska H., SiePaK J., Speciation of heavy metals in bottom sediments of lakes, Pol. J. Environ. Stud., 1999, 8 (5), 331.

[6] Szalińska E., Dominik J., Vignati D.A.L., Bobrowski A., BAs B., Seasonal transport pattern of chromium (III and VI) in a stream receiving wastewater from tanneries, Appl. Geochem., 2010, 25 (1), 116.

[7] Loizeu J.L., Arbouille D., SAntiago S., Vernet J.P., Evaluation of a wide range laser diffraction grain size analyser for use with sediments, Sediment., 1994, 41, 353.

[8] Persaud D., Jahgumagi R., Hayton A., Guidelines for the Protection and Management of Aquatic Sediment Quality in Ontario, Ontario Ministry of the Environment, Toronto, 1992.

[9] TuRekian K., Wadepon K., Distribution of the elements in some major units of the Earth's crust, Geol. Soc. Am. Bul., 1961, 72, 175.

[10] SZALIŃSKA E., DominiK J., BoBROwSKI A., BAS B., Fate of tannery chromium contamination in a stream. Temporal and spatial evolution of chromium(III) and chromium (VI), J. Phys. IV France, 2003, 107, 1275.

[11] Lis J., Pasieczna A., Geochemical Atlas of Poland 1:2 500 000, Państwowy Instytut Geologiczny, Warszawa 1995 (in Polish).

[12] MÜLlER G., Index of geoaccumulation in the sediments of the Rhine River, Geol. J., 1969, 2, 108.

[13] StofFers P., Glasby G.P., Wilson C.J., DAvis K.R., WATter P., Heavy metal pollution in Wellington Harbour, New Zeal. J. Mar. Fresh., 1986, 20, 495.

[14] KoRFALI S.I., DAVIES B.E., Speciation of heavy metals in sediment and water in a river underlain by limestone: role of carbonate species for purification capacity of rivers, Adv. Environ. Res., 2004, 8, 599.

[15] Kwapuliński J., Szilman E., Wiechula D., DeryŁo A., The occurrence of manganese in Goczatkowice dam reservoir, Acta Hydrobiol., 1992, 34 (1-2), 55.

[16] Loska K., Wiechula D., PelCZAR J., KwAPUlińSKi J., Occurrence of heavy metals in the waters of a heated reservoir (the Rybnik Reservoir, southern Poland), Acta Hydrobiol., 1994, 36, 267.

[17] GIERSZEWSKI P., SZMANDA J.B., LuC M., Distribution of bottom deposits and accumulation dynamics in the Wtoclawek Reservoir (central Poland), WSEAS Trans. Environ. Dev., 2006, 5, (2), 543.

[18] Sposito G., Skipper N.T., Sutton R., Park S., Soper A.K., Greathouse J.A., Surface geochemistry of clay minerals, Proc. Nat. Acad. Sci. USA, 1999, 96, 3358.

[19] ÇEVIK F., GÖKSU M.Z.L., DERICI O.B., FINDIK Ö., An assessment of metal pollution in surface sediments of Seyhan dam by using enrichment factor, geoaccumulation index and statistical analyses, Environ. Monit. Assess., 2009, 152, 309.

[20] SZAReK-Gwiazda E., CZAPlickA-Kotas A., SzalińsKa E., Background concentrations of nickel in the sediments of the Carpathian dam reservoirs (southern Poland), Clean - Soil, Air, Water, 2011, 39, (4), 368.

[21] MunK L., FAURE G., Effects of pH fluctuations on potentially toxic metals in the water and sediment of the Villon Reservoir, Summit County, Colorado, Appl. Geochem., 2004, 19, 1065. 